\title{
PUBLIC FUNDS AND THE INFORMATIONAL ACTIVITIES OF STATE AND LOCAL OFFICIALS
}

"The process of discovering what may be called the will of the society is a process of making it and to that process discussion is essential."

-A. D. LINDSAY

Casting an intelligent vote requires a judgment based upon adequate infor- mation. Placing information before the voter, however, may create a problem, since the presentation of biased information can prejudice his judgment. When the creators and carriers of information are public officials, operating with public funds and in a representative capacity, the problem becomes even more acute. This comment will examine the extent to which state and local officials are permitted to use public funds to present information to legislative bodies and to the electorate as a whole. In doing so, it will consider the kinds of information ${ }^{1}$ which can be presented in the light of the social policies affecting such activity.

\section{I}

The authority of a city to place information before a higher legislative body ${ }^{2}$ has been limited by the rule that a municipal corporation can exercise only those powers expressly granted to it, or necessarily implied from the powers that are granted. ${ }^{3}$ The extent of necessarily implied powers is not easy to determine, however, and many courts have construed the powers so strictly as to exclude the right to lobby. 4 Other courts, however, have employed a more liberal con-

1 Information about a given problem can be presented in three ways: (1) One may give only some of the facts, i.e., those which reinforce only one side of a debatable question, or (2) one may give all of the facts, or (3) one may give all the facts plus the conclusion that the presenter has reached on the basis of these facts.

: Usually the state legislature, though apparently no distinctions have been drawn between going to the state legislature and to Congress. Valentine v. Robertson, 300 Fed. 521 (C.A. 9th, 1924) (semble).

3 Port of Seattle ex rel. Dunbar v. Lamping, 135 Wash. 569, 238 Pac. 615 (1925); Valentine v. Robertson, 300 Fed. 521 (C.A. 9 th, 1924). This rule of contruction may not apply where the city has a home rule charter. Hays v. City of Kalamazoo, 316 Mich. 443, 25 N.W. 2d 787 (1947), giving the city a general grant of rights and powers, subject only to enumerated restrictions. Not all home rule charters are given this construction, however. E.g., Consumers Coal Co. v. City of Lincoln, 109 Neb. 51, 189 N.W. 643 (1922), where the city's powers were limited to those enumerated. Consult 2 McQuillin, Municipal Corporations $\$ 10.25$ (3rd ed., 1949).

1 Port of Seattle ex rel. Dunbar v. Lamping, 135 Wash. 569, 238 Pac. 615 (1925); Valentine v. Robertson, 300 Fed. 521 (C.A. 9th, 1924); Henderson v. City of Covington, 14 Bush (Ky.) 312 (1878). A public policy limitation has also been drawn when the lobbying was not limited to formal appearances or written arguments. Graves \& Houtchens v. Diamond Hill Independent School Dist., 243 S.W. 638 (Texas Civ. App., 1922); County of Colusa v. Welch, 122 Cal. 428, 55 Pac. 243 (1898). Interviews with the area's own legislative representative probably are permissible. See Valentine v. Robertson, 300 Fed. 521 (C.A. 9th, 1924). Lobbying contracts contingent on success are against public policy. E.g., Mich. Stat. Ann. (1952) $\$ 2.608$; Trist v. Child, 21 Wall (U.S.) 441 (1874). But in State ex rel. Hunt v. Okanogan County, 153 Wash. 399, 280 Pac. 31 (1929), the court failed to consider the contingent nature of the contract in allowing payment for lobbying. 
struction. Payment of counsel employed to assist in the reorganization of a street railway company, during which they drafted bills and appeared before a legislative committee, was allowed in an Illinois case. ${ }^{5}$ The city had the statutory right to construct, acquire or lease street railways and the court implied from this the right to "protect its interests either in court or before the state legislature."

In determining whether or not a municipal corporation has an implied power to lobby, some courts have drawn distinctions based upon the purpose of the lobbying or the type of body which wants to lobby. California has distinguished between lobbying for the extension of a city's facilities and lobbying for the protection of existing assets. ${ }^{7}$ Authority to lobby was found only in the latter situation. The Washington courts, after having held that a port authority could not lobby in the state legislature for reforms in its powers, ${ }^{8}$ allowed a county to press an equitable claim against the. United States in Congress. ${ }^{9}$ The court analogized the claim to the county's right to bring suit for debts due it and since this was within its express powers, the right to lobby was also present.

Quasi-municipal corporations are differentiated from municipal corporations in that they are created to perform only limited functions..$^{10}$ The distinction was used in a California case to grant the authority to lobby to an irrigation district after it had been denied to a city." It should be noted that in each case the distinction was drawn for the purpose of disregarding prior decisions in the jurisdiction which forbade lobbying.

In addition to the distinctions that have led courts to allow lobbying in the above cases, many of the lobby regulation statutes have specifically excluded from their registration provisions city officials acting in their official capacity. ${ }^{12}$

$s$ Baltzer v. City of Chicago, 260 Ill. App. 384 (1931).

- Ibid., at 396. See Hays v. City of Kalamazoo, 316 Mich. 443, 25 N.W. 2d 787 (1947), allowing membership in a municipal league and construing a home rule charter.

${ }^{7}$ Powell v. City \& County of San Francisco, 62 Cal. App. 2d 291, 144 P. 2 d 617 (1944), distinguishing Mines v. Del Valle, 201 Cal. 273, 257 Pac. 530 (1927), partially on this ground. The California statute giving cities the right to lobby did not control this case.

8 Port of Seattle ex rel. Dunbar v. Lamping, 135 Wash. 569, 238 Pac. 615 (1925).

9 State ex rel. Hunt v. Okanogan County, 153 Wash. 399, 280 Pac. 31 (1929).

${ }^{10} 1$ McQuillin, Municipal Corporations $\$ 2.28$ (3rd ed., 1949). Public corporations are divided into two categories, (1) municipal corporations, including cities, towns, villages and perhaps port authorities, and (2) quasi-municipal corporations, including, e.g., irrigation districts, school boards and most counties. Ibid., at $\$ 2.29$.

"Crawford v. Imperial Irr. Dist., 200 Cal. 318, 253 Pac. 726 (1927).

12 E.g., Ann. Laws Mass. (1952) c. 3, \& 50; N.Y. Legislative Law (McKinney, 1952) Legislation $\$ 66$; Gen. Stat. Kan. Ann. (1949) c. 46, $\$ 209$. The statutes operate on the principle that publicity is more effective than prohibition. Sen. Rep. No. 1400, 79 Cong., 2d Sess. 27 (1946). Consult 56 Yale L. J. 304 (1947) for an analysis of the federal regulatory act and the similar state statutes. For the history of the Federal Regulation of Lobbying Act, consult Schriftgiesser, The Lobbyists (1951). 
The implication of such statutes is that city officials can lobby..$^{13}$ Moreover, the express right to lobby has been given to city officials in at least two states. ${ }^{14}$

In contrast to the vigorous litigation over the right of a city to lobby, state activity in this field has apparently been uncontested. The official expression of a state's views on questions in which it has a legitimate interest is common practice. ${ }^{15}$

II

When the field of view changes, and those who are to be informed are the electorate as a whole, the courts have two problems to consider: (1) the authority to present information, and (2) the kind of information that can be presented. The cases on the municipal corporation level turn on the authority issue, and are decided against the authority to provide information. ${ }^{16}$ However, dicta in a recent New Jersey case involving the overzealous efforts of a school board to publicize a forthcoming vote on a bond issue indicated that, had the information presented there been unbiased, the expenditure of public funds for this purpose would have been permissible. ${ }^{17}$ Another New Jersey court commented on the requirement of a fair presentation in a case involving a commission which was set up to study Newark's form of government and expressly authorized to issue a report. ${ }^{18}$ One member of the commission objected to the distribution of 3,000 copies of the report without the inclusion of his minority report. The court approved the commission's action, however, since the precise points made by the dissent had, in fact, been included in the commission's report. The court held that, even though the expression of a conclusion was legitimate since it had been specifically authorized, the presentation of facts had to include all relevant data.

A somewhat different question is presented when a municipal corporation wishes to publicize its views on an issue that is being presented to the voters of the entire state. The situation is similar, but not precisely analogous, to both the lobbying activities of a municipal corporation toward a higher legislative body and the informational activities of a municipal corporation toward its own electorate. It is not the former since some of the voters to be reached are its own residents; not the latter since the electorate is not its own. The courts have not considered this a distinct situation, probably because they have also tended to blur the lines between lobbying and providing information for the municipal

${ }^{23}$ The precise form of lobbying in which city officials can impliedly engage is not certain. See the discussion of public policy restrictions on some lobbying activities in note 4 supra.

14 Ann. Laws Mass. (1944) c. 40, \& 5(15); Deerings Cal. Gen. Laws (1944), Act 4276, \&1, p. 1506.

${ }^{15}$ Nixon, So. Governors' Conference as a Pressure Group, 6 Journal of Politics 338 (1944).

${ }^{16}$ Elsenau v. City of Chicago, 334 IIl. 78, 165 N.E. 129 (1929); Mines v. Del Valle, 201 Cal. 273, 257 Pac. 530 (1927); cf. Sims v. Moeur, 41 Ariz. 486, 19 P. 2d 679 (1933).

17 Citizens to Protect Public Funds v. Board of Education, 13 N.J. 172, 98 A. 2d 673 (1953). In each of the cases cited in note 16 supra, the information was biased.

18 Giblin v. Charter Commission of City of Newark, 99 A. 2d 445 (N.J. Super. Ct., 1953). 
corporation's own electorate. ${ }^{19}$ The municipal corporation has been denied the authority to distribute information in this situation. ${ }^{20}$ Since the cases have turned on the issue of authority, the courts have not considered the kind of information presented.

The informational activities of the states toward their own electorate are largely governed by statute. ${ }^{21}$ The procedure for sending information is clearest in those states which have the initiative and referendum, ${ }^{22}$ though the practice is not limited to these states. ${ }^{23}$ Only nineteen states have the initiative and referendum. ${ }^{24} \mathrm{~A}$ consideration of the law of these states is useful, however, to illustrate the methods used and the problems raised in those states that have made the greatest attempt to cope with the need for information. Such statutes usually provide that the proponents of an initiative are to write an argument in favor of the legislation. A representative of the other side is then picked to prepare an argument in opposition. ${ }^{25}$ The arguments, together with the text of the legislation, are then mailed to every voter before the election. In recognition of the importance of this material, it has been held that the issue cannot be put on the ballot unless this information has gone to the voters. ${ }^{26}$

Litigation has also arisen concerning the material that goes onto the ballot itsclf. $\Lambda$ summary of the proposition, instead of the full text, is usually placed on

19 Compare Citizens to Protect Public Funds v. Board of Education, 13 N.J. 172, 98 A. 2d 673 (1953), with City Affairs Committee v. Board of Comm'rs, 134 N.J.I. 180, 46 A. 2d 425 (F.. \& A., 1946), and State ex rel Port of Seattle v. Superior Court, 93 Wash. 267, 160 Pac. 755 (1916), with Port of Seattle ex rel. Dunbar v. Lamping, 135 Wash. 569,238 Pac. 615 (1925).

${ }^{20}$ State ex rel. Port of Seattle v. Superior Court, 93 Wash. 267, 160 Pac. 755 (1916). Shannon v. City of Huron, 9 S.D. 356, 69 N.W. 598 (1896). Contra: City Affairs Committec v. Board of Comm'rs, 134 N.J.L. 180, 46 A. 2d 425 (E. \& A., 1946). The latter case has apparently been overruled on its biased information point by a case in which the city's activities wcre confined to its own electorate. Authority cited note 17 supra.

${ }^{21}$ The authority limitation so dominant in the minicipal corporation cases does not, of course, apply to states. Where the city council may be subject to a rigid interpretation of its express powers, the state legislature exercises general legislative powers, subject only to constitutional limitations.

22 The initiative is a procedure for putting new proposals before the legislature or the people, while the referendum is a veto reserved by the people over enactments of the legislature.

${ }^{23}$ E.g., MIl. Rev. Stat. (1953) c. $7 \frac{1}{2}, \S 2$.

24 Coigne, Statute Making 29 (1948).

${ }^{25}$ In Ohio, the opposing representative is picked by the General Assembly or the Governor. The arguments are not to exceed 300 words. Throckmorton's Ohio Code Ann. (Baldwin, 1948) $\$ 4785-180 \mathrm{a}-\mathrm{c}$. Massachusetts allows a 500 word argument by one chosen by the state secretary. Ann. Laws Mass. (1953) c. 54, $\$ 54$. Where the measure has been considered by the legislature, the state also publishes the majority and minority reports of the legislative committee. Mass. Const. Amend. XLVIII, $\$ 174$.

28 Kerby v. Griffin, 48 Ariz. 434, 62 P. 2d 1131 (1936). But cf. Hart v. Jordan, 14 Cal. 2d 288,94 P. $2 d 808$ (1939), where the statutory procedure conflicted with a constitutional mandate. 
the ballot. ${ }^{27}$ The summary must be both fair ${ }^{28}$ and indicative of all material provisions of the proposal. ${ }^{29}$ Information in addition to the summary probably would not be allowed on the ballot..$^{30}$ However, if the proposition is attacked after it has been approved by the voters, the courts have discounted objections that could have been brought before the balloting. ${ }^{31}$

\section{III}

- It should be noted that the cases are litigated in terms of the authority of the municipal corporation to provide information. It is submitted, however, that the important consideration is the voters' need for information. There are two possible methods of supplying this need and thus making intelligent discussion possible. Traditionally, the need has been served through an adversary procedure in which competing points of view are presented by those interested in the issue under debate. This method assumes that the correct alternative will be presented and that its validity will be recognized. The other possible procedure is the dispassionate presentation of data by an expert. The expert's function is to make clear the rational alternatives present in a social situation. The decision, however, must rest entirely on discussion among the voters, and the expert, therefore, is not allowed to present his conclusions. ${ }^{32}$

The traditional adversary method has been adopted by the legislatures. Since the need for information must be supplied by those interested in the legislation, the legislator must have an opportunity to hear all such parties. When the proposed legislation affects a municipal corporation's functions, the municipal corporation represents a large group of interested parties. Further, to the extent

${ }^{27}$ The Ohio Supreme Court, considering a constitutional amendment, held that a full statement of the proposition must go on the ballot. State ex rel. Greenlund v. Fulton, 99 Ohio St. 168,124 N.E. 172 (1919). The court was forced to limit this requirement to constitutional amendments when presented with a sixty-seven page amendment to the Cleveland City Charter. Reutners v. City of Cleveland, 107 Ohio St. 117, 141 N.E. 27 (1923).

${ }^{28}$ Senior Citizens League v. Department of Social Security, 38 Wash. 2d 142, 228 P. 2d 478 (1951); Wieder v. Hoss, 143 Ore. 122, 21 P. 2d 780 (1933).

${ }^{29}$ Sawyer Stores v. Mitchell, 103 Mont. 148, 62 P. 2d 342 (1936), throwing out summary that neglected to recount the source of funds to be raised when source was part of the proposal; Sears v. Treasurer \& Receiver General, 327 Mass. 310, 98 N.E. 2d 621 (1951).

${ }^{30}$ See Knappenberger v. Hughes, 377 Ill. 126, 35 N.E. $2 d 317$ (1941).

31 State ex rel. Graham v. Board of Examiners, 125 Mont. 419, 239 P. 2d 283 (1952), wrong voters may have participated in the balloting; Mayer v. Adams, 182 Ga. 524, 186 S.E. 420 (1936), inadequate publication; Weisgerber v. Nez Perce County, 33 Idaho 670, 197 Pac. 562 (1921), publication too late.

20 "But their expertness is not shown in framing and executing policies, but in discovering and making known the facts upon which the former depend." Dewey, The Public and Its Problems 208 (1927). Dewey's emphasis is on the interaction among members of society that the discussion will promote. The important thing is not the decision reached, but rather, the way in which "a majority comes to be a majority." Ibid., at 207. The role of the expert is also discussed in Knight, The Ethics of Competition 69 et seq. (1935). 
that the municipal corporation possesses expertise in its affairs, even a biased presentation will include data valuable to the legislator. For these reasons, the increasing recognition by the courts of the right of the municipal corporation to lobby seems proper. The same rationale extends to lobbying by the states, though apparently no objection has been made to their activities in this field. ${ }^{33}$

When those who are to be informed are the electors as a whole, either method of presenting information could be utilized. In practice, the municipal corporation has not been permitted to use either the adversary or the expert method, because the requisite authority has been lacking. ${ }^{34}$ Municipal corporations have, however, provided information without using public funds. Private communications media disseminate news about the operation of governmental units with the assistance and often at the solicitation of public officials. In addition, municipal corporations, or their subdivisions, publish reports which summarize the year's activities and suggest future policy. Neither of these sources, however, is an entirely reliable means of fulfilling the voter's need for information. Private media are neither obligated to provide information nor noted for their accurate presentation of the relevant data. ${ }^{35}$ Official reports, although they contain important information, are not designed to provide information on particular referenda issues. Since the municipal corporation often possesses the needed information, it would seem desirable to insure the voter of its availability. Given legislative authorization, the municipal corporation could appropriately use the expert's presentation of the facts to help meet the voter's need for information. This method is open to the objection that a completely impartial statement of the facts is not possible. It can be argued, however, that the slight degree of advocacy innate in such a presentation is a legitimate concession to the desirability of providing a basis for intelligent discussion. The municipal corporation could also present information through the use of an adversary procedure such as that adopted by many states. ${ }^{36}$ The major objection to this method is that the competence of the arguments that the voter receives depends entirely on the ability of whoever happens to draw them.

The use of some procedure for sending information, whether it is the expert's analysis of the facts or the presentation of opposing points of view, seems desirable. Once one has accepted the need for information, the restrictions that have been placed on the use of public funds for this purpose appear oppressive. Care need only be taken that their use be fair-and serve the end of promoting informed discussion among the electors.

23 Authority cited note 15 supra.

34 Cases cited notes 16 and 20 supra.

${ }^{35}$ See, for analysis and recommendations, Commission on Freedom of the Press, A Free and Responsible Press (1947), especially c. 6. supra.

${ }^{36}$ Discussion of informational procedures in the initiative and referendum states, page 477 